\title{
Ethnic Conflict and Sustainable Development in Nigeria: The Role of Peace Education
}

\author{
Alonge, Rufus A. \\ Department of Educational Foundations and Management, \\ Faculty of Education, \\ Ekiti State University, Ado-Ekiti, Nigeria \\ E-mail: topeajayi03@gmail.com \\ Okunade, Helen F. \\ Department of Educational Foundations and Management, \\ Faculty of Education, \\ Ekiti State University, Ado-Ekiti, Nigeria \\ E-mail: okunadehf@yahoo.com
}

\begin{abstract}
The issue of ethnic conflict in Nigeria has become a burning national issue with its attendant problems. Its current predominance is reflected in the reports of various activities of ethnic militant in the country coupled with the high rising terrorism activities in the northern part of the country from which the traces of ethnicity problem cannot be totally ruled out. However, the issue now nationwide is no longer the recognition of ethnic conflict and its increasing threats to lives and properties but on how to curtail and manage it so that both human and material resources being used for such activities can be geared towards bringing about sustainable development in all spheres of life. The problem could best be tackled through deliberate and sincere efforts to change the behaviour and attitudes of the people to become their brothers' keeper and tolerate one another. This could best be achieved upon the teaching of peace education in the schools. Therefore, this paper discusses ethnic conflict, reviews its trends and management and finally highlights the strategy for ethnic conflict resolution and management in Nigeria.
\end{abstract}

Keywords: Ethnicity, Ethnic Conflict, Peace Education, Social Justice, Sustainable Development

\section{Introduction}

Nigeria as one of the developing countries in the world is one of the countries where ethnic pluralism is well pronounced. The country has more than two hundred and fifty (250) different ethnic groups whose cultures and values vary widely. However, this has brought a lot of rivalries among the ethnic groups in Nigeria resulting into violence and skirmishes. Ethnic conflicts have become the serious challenge of our times, coming as a result of the allocation of scarce resources, multiculturalism, religion, and militarization of ethnicity among others. Considering the importance of peace globally and the consequences of conflicts, it is very clear that Peace Education is very germane in the sustenance of socio-economic development of any nation and because of the benefits to be derived from its introduction into the school system it therefore requires a widespread recognition. This paper, therefore, attempts to examine the implication of ethnic conflict on sustainable development and also to suggest how peace education can serve as antidote to ethnic conflicts in Nigeria.

\section{Ethnic Groups and Conflicts}

Ethnic Group means different things to different people. Just as we have many authors, so we have several definitions of the concept. The following are the most frequently-used definitions of ethnic groups:

Ethnic group is viewed as a biological group with the same culture, symbols and communication sharing a peculiar identifiable characteristics including membership (Naroll, 1964).

Ethnic groups are viewed as the categories of people characteristics by cultural criteria symbols including language, value systems and normative behaviour, and whose members are enclosed in a particular part of the new state territory (Otite, in Omotosho 2008).

An ethnic group is a group of people that have the same biological texture of hair, colur of the skin, eye as well as the structure of the nose among the features (Okodo in Paulley 2012). 
It is believed that ethnic groups should possess the following characteristics: common geographical origin, race, language or dialect, religious faith, shared traditional values and symbols, literature, folklore and music, food preference, and internal and external sense of distinctiveness (Thernstrom, 1980).

Those definitions contain several points in common among which are the language, values, religious faith, etc. The concept of conflict is defined as a struggle over values or claims to status, power and scarce resources, in which the aims of the conflicting parties are not only to gain the desired values but also to neutralize, injure or eliminate their rivals (Otite, 1979). Clarifying this, Abegunde (2006) pointed out that conflict implies struggle, competition, contest or disagreement between the participants over valued and scarce resources in which the aim of the participants is to have advantage over each other in the control of such resources. Hence, conflict is unavoidable in human affairs because society is formed on the basis of conflict and conflict resolution to move forward and make individuals in it better persons. It is believed in some quarters that conflict is a good instrument for resolving crisis in the society provided that it is not allowed to escalate into violence.

Putting the two concepts together, ethnic conflict simply occurs when there is a breakdown of accommodation of ethnic minorities and majorities within a state. This implies that, when there is a breakdown of communication from whichever source, which leads to stiff and unhealthy competition among the parties concerned, ethnic conflict may be said to have risen. The major causes of ethnic conflict in Nigeria include: the denial of identity, fear of domination, resources allocations, value differences, and denial of human other needs which could include the need for safety, security, love, sense of belonging, self esteem and ability to attain one's goals (Abegunde, 2006; Omotosho, 2008; Dibal, 2011).

\section{Trends and Dimensions of Ethnic Conflict in Nigeria}

Ethnic conflicts could take different forms and its manifestation could arise from different dimensions in the Nigeria society. It could manifest in the area of religion, economy, education, military, politics, and among professionals.

On the economic aspect, members of ethnic groups who have attained a higher position in their chosen career use such an opportunity to give better economic benefits to their group members. Others influence the location of certain industries in their ethnic environment without considering the suitability of such industries in the area. On religion, the country has witnessed many ethnic conflicts, as a result of religion. The current wave of Boko Haram insurgence in the country is an important example. Many lives and properties have been lost in the course of this. The two major religions in the country see themselves as superior to each other. Furthermore, among the same religious group, ethnic conflict still manifests. This was rightly observed by Omotosho (2008) that Muslims from the northern part of the country will not allow a fellow Muslim Southerner to lead prayer in the northern mosque based on the assumption that a non-Hausa is not qualified to do so and vice versa. Ethnic conflict among the professionals cuts across many professions in the country be it military, academic, business. Military recruitment and coup d'etat in the country have always been with ethnic colouration to establish ethnic dominance on other ethnic groups in the country. The businessmen and women of different ethnic groups are found disagreeing on several issues and the root cause is usually affirmed to be on ethnic factors. For instance, Hausa and Yoruba clashed in Ibadan 1999 at Bodija Market over cattle (Omotosho, 2008).

The incessant eruption of ethnic conflict leading into violence in Nigeria has revealed the failure of government and its institutions saddled with the responsibility of conflict management and prevention of violence. So it is pertinent to look beyond government and institutional strategies to solve the problem by not allowing conflict to degenerate into violence that end up claiming the lives of thousands of people and destruction of properties worth millions of Naira. Among several remedies, the best is the impartation of knowledge that is aimed at changing the beliefs and the attitudes of the people toward fellow Nigerian, and not minding the ethnic background. This can best be done through the establishment of Peace Education Programme in our schools possibly from the primary schools to the higher institutions.

\section{Strategies for Ethnic Conflict Resolution}

Various strategies have been employed by various governments in Nigeria to curb ethnic conflicts from degenerating into full-flagged violence such as : the establishment of Nigeria Inter-Religious Council (NIREC) by President Obasanjo in 2001, and the creation of the office of a special Adviser on ethnicity and peace by the same government (Federal Government of Nigeria, 2001). The Amnesty offer for the Niger/Delta militia by the Yar'Adua/Goodluck administration was also directed towards checkmating ethnic conflicts from being metamorphosised into violence ((Federal Government of Nigeria, 2007). All these measures have not been able to achieve the desired result, because it has not been able to address the mindset and attitudinal changes of the citizenry. To put the round peg in the round hole, there is one strategy that is very important and that is Peace Education. Peace Education is defined as the process of acquiring the values, the knowledge and developing the attitudes, skills and behaviour to live in harmony with oneself, with others, and with the natural environment (Wikipedia, 2013).

UNICEF (1999) defines Peace Education as the process of promoting the knowledge, skills, attitudes and values needed to bring about behaviour changes that will enable children, youth and adults to prevent conflict and violence, both overt and structural to resolve conflict peacefully, and to create the condition conducive to peace, whether at an interpersonal, intergroup, national or international levels. Peace Education is aimed at reducing conflict and to live peacefully in the society. Peace strives on justice and fairness, equity, trust, friendship, mutual respect, communication, a common aspiration and similar elements. Peace building as core message of peace education involves identifying and supporting indices and structures which will consolidate peace and will allow trust to enhance interaction and prevent the recurrence of conflict (Dibal, 2011). Peace education is a necessary tool to be used to plant and nurture the culture of peace. 
Culture of Peace involves a set of values, attitudes, modes of behaviour and ways of life that reject violence and prevent conflicts by tickling their root causes to solve problems through dialogue and negotiation among individuals, groups and nations (Galtung in Ogunyemi, 2006). He went further to highlight the conditions for peace and non-violence culture to prevail as: fostering a culture of peace through education, promoting sustainable economic and social development, promoting respect for all human rights, ensuring equality between women and men, and also fostering democratic participation.

It is believed that a culture of peace could be achieved when citizens of the world understand global problems, have the skills to resolve conflict and struggle for justice non-violently ((http://www.un.org/ cyberschnolbus/peace/content2.htm) downloaded June 30. Because of the importance attached to global peace by the United Nations, in the year 1997 the United Nations General Assembly (UNGA) declared the year 2000 as the International Year for the Culture of Peace. Not only that, in the year 1998 the UNGA declared 2008 - 2010 the International Decade for a Culture of Peace and Non-violence for children of the World (UNESCO, 2002). Education being the light that shows the mankind the right direction to surge and its purpose is not only to make man literate but also adds to rational thinking, knowledge ability and self sufficiency. The United Nations General Assembly believes that to achieve the culture of peace and other resolutions and declarations, education cannot be overemphasized in collaboration with the United Nations Education Scientific and Cultural Organisation (UNESCO).

Peace Education in School will influence the child to cultivate peace value, the child will grow to be non-violent and recognize human rights and embrace democracy. Its inculcation into the school curriculum will help to focus on the fundamental values of democracy, large generosity of mind, care and compassion.

UNESCO in Dibal (2011) positioned that peace education for the $21^{\text {st }}$ century should centre on equipping the learner with knowledge, values and skills with emphasis on a better understanding and appreciation of other culture, mutual respect and contributing to the objectives for the world decades for cultural development. If other people's culture is appreciated, the issue of ethnic conflict would be abated as members would dwell safely and live together in peace. Oluwagbohunmi, Osalusi and AbduRaheem (2013) appreciated the need to educate the young ones about people's culture and values with the belief that this is going to promote healthy relationship among members of the society and it will go a long way to instill in the young people the importance of respecting other people's rights and values/beliefs. They are of the opinion that if peace education is taught in Nigerian schools, it will greatly help our youths to put up better attitudes that disdain and eschew violence in the society.

Furthermore, peace education is a strong vehicle of development. Without peace people's attention will be disturbed and they cannot concentrate on anything meaningful and worthwhile. Apart from this, crises affect the socio-economic development of the country as this will go a long way to deprive the industrialists from establishing industries, and consequently foreign investors will not like to come and also those on ground may want to quit. More so, there is going to be an increase in capital flight from both the local and foreign investors and lastly on the part of the government, much capital vote and other non-budgeting allocation/expenses will be expended on security.

As it was stated above that peace is a strong vehicle of development, it is obvious then that, without peace development cannot take place and be sustained and in order for development to be sustained, we must give peace a chance and this can be done through the incorporation of peace education into the school curriculum in Nigeria. Presently the Bill is still before the National Assembly on the establishment of Peace Studies in our schools right from the primary school to the higher institution level. Although many state governments have adopted Peace corps or peace clubs in the schools, and some universities have also incorporated peace and Conflict Studies into their GST courses, there is need to start the inculcation of an ideal norm that emphasize the peaceful co-existence among the different ethnic groups in Nigeria right from the children in the primary school because they are yet to have a mind set on any issue and so they can grow into a peaceful co-existence with other ethnic groups in the country.

Peaceful co-existence is germane to socio-economic development of any nation and because of this, there have been calls from different quarters for Peace Education. The authority of Afe Babalola University, Ado-Ekiti in her annual Lecture titled "A clarion call for peace in Nigeria" advocated among the twenty-one points communique reached at the end of the lecture that civic and peace education should be introduced in schools to inculcate patriotism and the culture of peaceful methods of managing conflict in Nigeria (www.abuad.edu.ng.accessed11/11/2013). Also Punch Newspaper of (13 July, 2012) came out with a caption proprietor advocates peace education for children" the reason given was that children could appreciate the significance of international peace and development by enabling them to overcome bias and prejudice.

\section{Conclusion and Recommendation}

This paper has suggested the adoption of an appropriate technique/strategy through which ethnic conflict can be resolved and possibly curtailed through the introduction of peace education in Nigeria. Education as a dynamic instrument of change is the key to unlock all problems. Education will expose citizens to live by international standards of human rights and equity appreciation of cultural diversity and respect each other's rights. Such learning can only be achieved with systematic education for peace. Furthermore, the maintenance and promotion of peace and peaceful coexistence for all round development is the responsibility of all Nigerians. Since conflict cannot be avoided in any society, it is always good to take steps to manage it so as not to perpetuate violence. The right time is now for the government to introduce peace at all levels of education considering the enormity of the crises that may unfold if we refuse to address the problem of ethnic conflict in Nigeria. 


\section{References}

Abegunde, O. (2006). Inter-ethnic violence in Nigeria: The problems with the solution. A. A. Agagu \& Femi Omotoso (eds.) Essays on Nigerian People, Culture and Politics. Chapter Thirteen. GST Unit, University of Ado-Ekiti.

Dibal, Salmanza (2011). Peace education and national development. International and National Journal of Research in Education. 8 (1) 264-268.

Federal Government of Nigerian (2001). Draft national youth policy and strategic plan of action. National youth summit working document. Government Press.

Naroll, R. (1964). Ethnic unit classification. Current Anthropology. 5(4) 4 Oct.

Ogunyemi, B. (2006). Contemporary issues in social studies education. CSIT Dept., OOU. Ago-Iwoye: Franco-Ola Printers.

Oluwagbohunmi, M. F.; Osalusi, F. M. \& Abdu-Raheem, B. O. (2013). Peace education: Panacea for combating conflicts and violence in Nigeria. Journal of Social Studies Association of Nigeria (SOSAN). XVI(2): 253 -264.

Omotosho, B. J. (2008). The ethnic dimension of conflict. A. A. Agagu, Femi Omotoso \& Ola Abegunde (eds). Peace and Conflict Studies in Nigeria. GST Unit, University of Ado. Chapter 5.

Otite, O. (1979). Ethnicity and class in a plural society in Nigeria. G. B. Marret \& J. Cleggan (eds). Research in Race and Ethnic Relations. 1(2).

Paulley, F. G. (2012). Cultural pluralism and Nigerian unity: The role of social studies education. Nigerian Journal of Social Studies. XV(3): 44-57.

Punch Newspaper 13 July, 2012.

Thernstrom, S. (1980). Introduction . In S. Thernstrom (ed) Harvard Encyclopedia of American Ethnic Groups; Cambridge: The Belknap Press at Harvard University Press.

UNESCO (2002). UNESCO: Mainstreaming the culture of peace. Paris: United Nations Educational, Scientific and Cultural Organisation.

www.abuad.edu.ng.accessed 11/11/2013.

Wikipedia. Meaning of peace education. Free encyclopedia. sen.wikipedia.or/wiki/peace edu. Retrieved 02/11/13. 